Article

\title{
The Spatial Differentiation of the Suitability of Ice-Snow Tourist Destinations Based on a Comprehensive Evaluation Model in China
}

\author{
Jun Yang ${ }^{1, *}$, Ruimeng Yang ${ }^{1}$, Jing Sun ${ }^{1}$, Tai Huang ${ }^{2,3, *}$ and Quansheng Ge ${ }^{3}$ \\ 1 Liaoning Key Laboratory of Physical Geography and Geomatics, Liaoning Normal University, \\ Dalian 116029, China; yrm127@163.com (R.Y.); dlhbbgs@163.com (J.S.) \\ 2 Department of Tourism Management, Soochow University, Suzhou 215123, China \\ 3 Key Laboratory of Land Surface Patterns and Simulation, Institute of Geographic Sciences and Natural \\ Resources Research, CAS, Beijing 100101, China; geqs@igsnrr.ac.cn \\ * Correspondence: yangjun@Innu.edu.cn (J.Y.); huangtai_fx@163.com (T.H.)
}

Academic Editors: Jun Liu, Gang Liu and This Rutishauser

Received: 1 February 2017; Accepted: 4 May 2017; Published: 8 May 2017

\begin{abstract}
Ice, snow, and rime are wonders of the cold season in an alpine climate zone and climate landscape. With its pure, spectacular, and magical features, these regions attract numerous tourists. Ice and snow landscapes can provide not only visually-stimulating experiences for people, but also opportunities for outdoor play and movement. In China, ice and snow tourism is a new type of recreation; however, the establishment of snow and ice in relation to the suitability of the surrounding has not been clearly expressed. Based on multi-source data, such as tourism, weather, and traffic data, this paper employs the Delphi-analytic hierarchy process (AHP) evaluation method and a spatial analysis method to study the spatial differences of snow and ice tourism suitability in China. China's ice and snow tourism is located in the latitude from $35^{\circ} \mathrm{N}$ to $53.33^{\circ} \mathrm{N}$ and latitude $41.5^{\circ} \mathrm{N}$ to $45^{\circ} \mathrm{N}$ and longitude $82^{\circ} \mathrm{E}$ to $90^{\circ} \mathrm{E}$, with the main focus on latitude and terrain factors. A poor fit is concentrated at latitude $20.45^{\circ} \mathrm{N}$ to $35^{\circ} \mathrm{N}$ and longitude $100^{\circ} \mathrm{E}$ to $122^{\circ} \mathrm{E}$; the difference is that the latitude is low and affected by the Japanese warm current. The analysis of the suitability of ice and snow tourism can be employed as a reference for the development of ice and snow tourism.
\end{abstract}

Keywords: suitability; ice-snow tourism; tourist destinations; comprehensive evaluation; spatial differentiation; China

\section{Introduction}

Ice-snow tourism includes activities that originated in nations located in cold climate zones. Ice-snow tourism is a type of ecological tourism and is the generic term for tourism that involves experiencing snow and ice culture based on the tourism resources of icy and snowy climates [1]. In recent years, China's economy has strengthened, and the concept of national leisure time has resulted in a boom in leisure tourism. The winter landscape is unique, and citizens throughout the nation have a seven-day holiday during the traditional Chinese "New Year (Spring Festival)". Therefore, an increasing number of people are choosing to travel during the winter season. An evaluation in the report by the National Tourism Administration indicates that 14.802 million tourists visited Jilin Province during the 2015 Spring Festival, an increase of 15.53\% from the previous year, and 14.784 million tourists visited Liaoning Province, an increase of $11.7 \%$. The total income from tourism was 10.38 billion RMB Yuan, an increase of $12.4 \%$. The development of ice-snow tourism is robust and quick, which has led to general concern among government departments and the scientific community, and it has also become a popular research topic. 
Ice and snow tourism belongs to the category of ecotourism; it is a type of tourism product in which the participation of snow and ice climate tourism resources is the main tourist attraction for experiencing an ice and snow culture. It is a highly participatory tourism product that is primarily divided into sightseeing (isce, snow, and rime), sports and leisure (skating, ice car, curling, skiing, snow ballet, and mountain snow), festivals, events (professional events and fun events), pleasure classes (ice and snow playground, snow recreation projects, ice recreation projects, etc.), performing arts, and other experience classes.

Currently, ice-snow tourism countries are principally concentrated on developments in Europe and North America, and it is generally studied from two perspectives, predictions of stationary analyses with correlated models and predictions of dynamic analyses with developing trends. May analyzed the environmental impact of the 1992 Winter Olympic Games, and Hudson [2] and Sharpley analyzed cases of international ski travel in a typical application of stationary analysis [3]. Dewar et al. used cross-cultural means to compare ice-snow tourism products in North America and Harbin [4]. Scott et al. analyzed the ski industry in Quebec in a typical application of dynamic analysis [5]. Considering climate change, Burakowski et al. performed a systematic analysis of the impact of winter temperatures on the winter tourism economy in the USA [6]. DemiRoglu et al. considered using three resorts as an example and analyzed the impact of climate on natural snowfall, artificial snow, and wind on snow and ice resorts [7]. Scott et al. analyzed ice and snow tourism from the perspective of the vulnerability of climate change [8].

Ice-snow tourism in China is mainly divided into seven perspectives: concept and connotation, resource development, ski touring, sustainable development, economic growth, marketing, and tourism position. This paper mainly studies regional ice-snow tourism; at present, most ice-snow tourism development occurs in the Heilongjiang and Jilin provinces. Zhang et al. combined the structure of the tourism market in Jilin, based on the resource advantages, and came up with a development strategy for ice-snow tourism in Jilin [9]. Huang analyzed the advantage of creating ice-snow tourism in Harbin, concluded that Harbin has extensive resources and brand advantages, and proposed a strategic plan for the construction of ice-snow tourism in Harbin [10].

The primary methods used in researching ice-snow tourism in China include an analytic hierarchy process (AHP), a strengths, weaknesses, opportunities, and threats (SWOT) analysis, and a data envelopment analysis (DEA). The results are predominantly concentrated on the development and efficiency of regional ice-snow tourism. The research subjects are primarily in Northeast China. The results are most plentiful in the Heilongjiang area, where the studied content is also the broadest. An analysis of relevant studies indicates that skiing is the key sports program to develop in domestic ice-snow tourism and that ski resorts and tourism will become an important trend in development [11].

Studies of ice-snow tourism have primarily focused on strategies for developing regional ice-snow tourism; there has been little planning, design, or research on the content of micro-level development strategies [12]. The theoretical study of ice-snow tourism lags behind the current development status of domestic ice-snow tourism, and there is a lack of comprehensive analysis on the temporal and spatial differentiation of the ice-snow tourism industry on a national scale. In this paper, we analyze the characteristics of the spatial and temporal differentiation of ice-snow tourism on a national scale from various perspectives to provide a new perspective on, and way of thinking about, the development of ice-snow tourism.

\section{Data and Model}

\subsection{Data}

To ensure comparability and objectivity of the results, we selected data from a cross-section for the same time period in 2016. Quantitative studies require that we unify the quantitative processing of the index data. The sources of data selected in this paper and the information contained in the data are shown in Table 1. All required data were preprocessed by making appropriate deletions, 
checking for missing information before the data were used and unified to the same coordinate system for standardized treatment. Hong Kong, Macao, and Taiwan are not included in the data [13].

Table 1. Data sources and descriptions.

\begin{tabular}{ll}
\hline Data Source & Coverage Information \\
\hline $\begin{array}{l}\text { Data center of the Ministry of Environmental Protection of the } \\
\text { People's Republic of China (http://datacenter.mep.gov.cn/index) }\end{array}$ & Data of national and regional forest coverage \\
\hline $\begin{array}{l}\text { China Meteorological Data Sharing Network } \\
\text { (http://www.cma.gov.cn/2011qxfw/2011qsjgx/) }\end{array}$ & $\begin{array}{l}\text { National and regional temperature and snow data (December } \\
\text { to February) (756 basic stations and 112 radiation sites) }\end{array}$ \\
\hline Statistical database on China's economic and social development & $\begin{array}{l}\text { Data on the urban population, greenery, economy, traffic, and } \\
\text { regional production }\end{array}$ \\
\hline $\begin{array}{l}\text { China Yearbook Database: China Tourism Yearbook (2016) and } \\
\text { China City Statistics Yearbook (2016) }\end{array}$ & $\begin{array}{l}\text { Survey on tourism in China, regional tourism, bulletins, } \\
\text { policies, and regulations }\end{array}$ \\
\hline $\begin{array}{l}\text { National Tourism Bureau of the People's Republic of China: } \\
\text { Report on the development of tourist attractions in China (2016) }\end{array}$ & $\begin{array}{l}\text { Distribution of 5A scenic areas, star-level hotels, and travel } \\
\text { agency information }\end{array}$ \\
\hline $\begin{array}{l}\text { National Geographic Information Bureau } \\
\text { (http://www.sbsm.gov.cn/) }\end{array}$ & $\begin{array}{l}\text { Remote sensing images (used for the extraction of snow area), } \\
\text { administrative division and digital elevation data (unified to } \\
\text { use the 1980 geodetic coordinate system of Xi'an and the } \\
\text { Albers equal area conic projection) }\end{array}$ \\
\hline $\begin{array}{l}\text { China Traffic Atlas (plastic set) and Atlas of China's } \\
\text { Transport Operation }\end{array}$ & \begin{tabular}{l} 
Railway, road, and waterway networks and airports \\
\hline
\end{tabular}
\end{tabular}

\subsection{Suitability Model}

Suitability modeling identifies the optimal position for the specific object. Overlay analysis is one method used in suitability modeling; it applies a universal proportion to inputs of all types to create an integrated analysis [14,15]. The suitability model for ice-snow tourist destinations associates spatial attribute data and non-spatial attribute data based on graphic data and, therefore, quantitatively calculates spatial data, extracts an evaluation factor, and superimposes weighted elements. The process of spatial analysis to be studied primarily includes attribute associations, a spatial single-factor analysis, and a comprehensive superposition analysis [16]. That is, the dataset based on different factors is unified to the same level, and weights are assigned to the adaptive region to ensure that the process is scientific and objective [17]. We select the Z-score scoring method for standardized treatment of the original data to eliminate dimensional differences. We adopt the AHP method to obtain the scores and weights of different factors. The calculation method is based on Equations (1) and (2). We use Model Builder (ESRI, ArcGIS, Redlands, CA, USA) to obtain a comprehensive score and re-classify it. By adopting the multi-objective linear summation method, we calculate a comprehensive index for the suitability of ice-snow tourist destinations in coastal cities by summing the index scores and generating the corresponding regions to evaluate the spatial distribution of the results $[18,19]$. As the comprehensive index increases, the suitability of the analyzed ice-snow tourist destination increases [20]. The calculation method is shown in Equation (3). A specific diagram of the evaluation structure is shown in Figure 1.

$$
A_{i}=\frac{\sum_{j=1}^{n} c_{i j}}{n}
$$

where $A_{i}$ is the score of the $i$ th factor, $c_{i j}$ is the experts' and scholars' score for the $i$ th factor, $i$ is the $i$ th factor, $j$ is the $j$ th expert or scholar, and $n$ is the number of experts and scholars.

$$
B_{n}=\sum_{j=1}^{m} a_{i} b_{n}^{j}
$$

where $B_{n}$ is the weight of the objective layer, $a_{i}$ are the weights of different factors in the field layer with respect to the objective layer, and $b_{n}$ is the weight of the evaluation factor relative to the field layer. 


$$
S=\sum_{i=1}^{m}\left[\sum_{j=1}^{n} A_{j} \times b_{n}\right]
$$

where $S$ is the suitability index for a city as a tourist destination, $A_{j}$ refers to the value of the index for the $j$ th city, and $b_{n}$ is the weight of the evaluation factor layer. Here, $n$ and $m$ refer to the number of indices in the factor and field layers, respectively, of the evaluation system.

$$
\begin{gathered}
W_{i}=\frac{1-H_{j}}{n-\sum_{j=1}^{n} H_{j}} \\
W=n_{1} \times B_{n}+n_{2} \times W_{i}
\end{gathered}
$$

where $W_{i}$ is the entropy weight value, $H_{j}$ is the corrected information entropy, and $W$ is the comprehensive weight of each indicator. The reference coefficient is set to $n_{1}=n_{2}=0.5$.

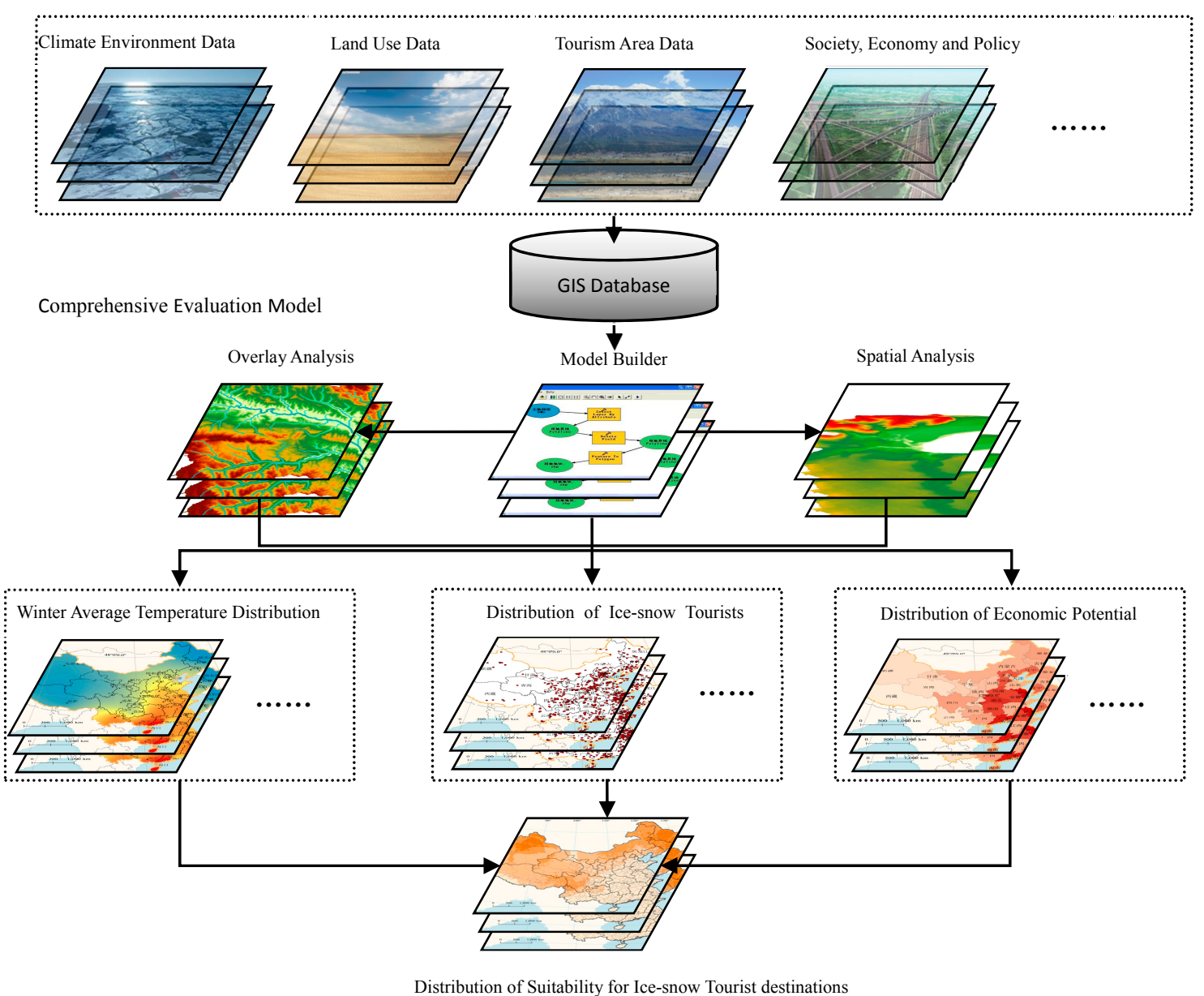

Figure 1. Technology roadmap.

Ice-snow tourism is a resource-oriented industry, and the development of ice-snow tourism depends rather strongly on the environmental basis of snow and ice resources [21]. Our study establishes an evaluation system for the comprehensive assessment from the three perspectives of industry resources, the state of development, and the potential for development, and it derives appropriate locations for ice-snow tourist destinations based on spatial overlap and the composite index [22]. The details of the evaluation system are presented in Table 2. 
Table 2. System for evaluating the suitability of ice-snow tourist destinations.

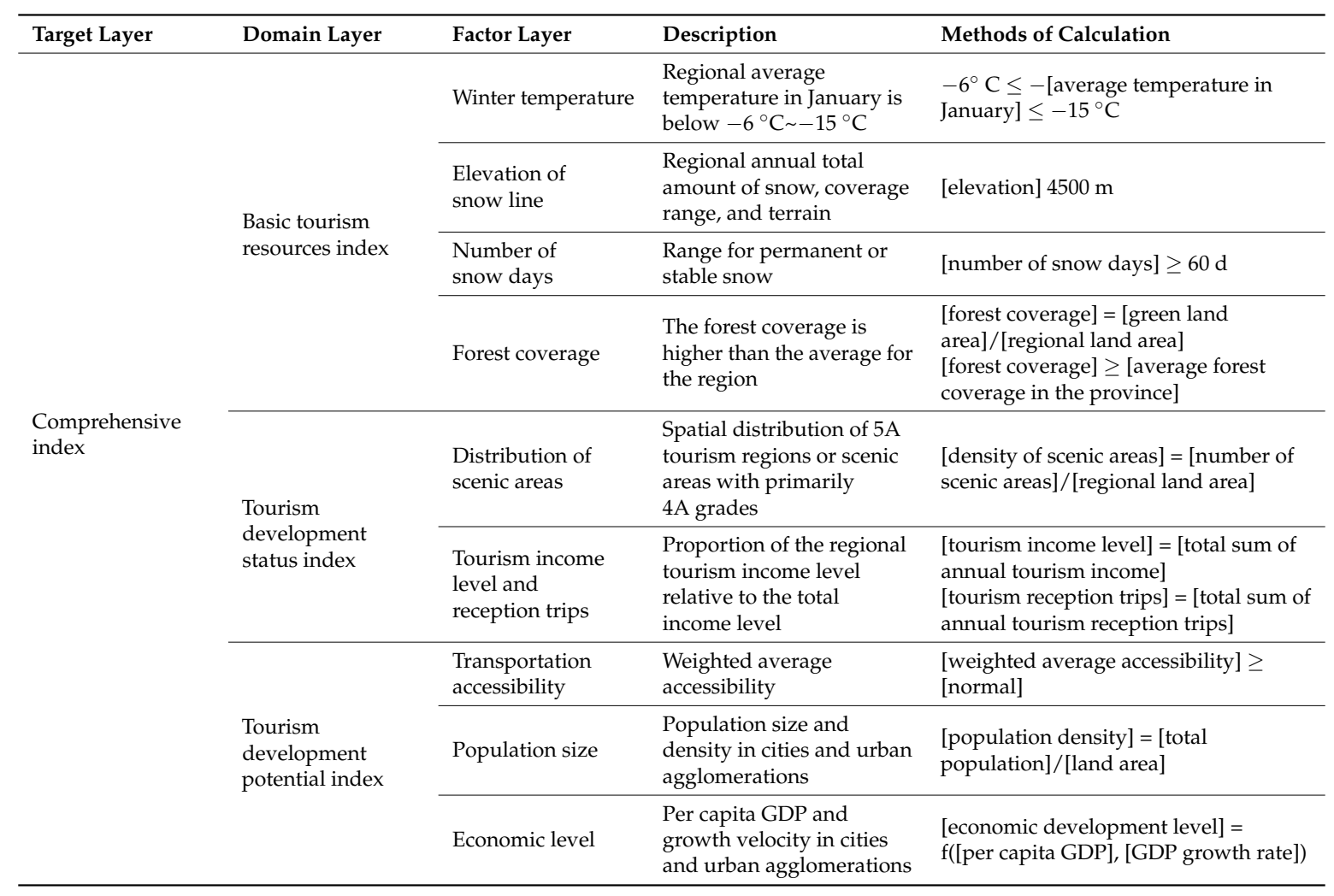

\section{Research Results and Analysis}

\subsection{Environmental Resource Index}

Ice-snow tourism is a resource-oriented industry, and the development of ice-snow tourism depends largely on resources [23]. China's total temperature, which indicates cold temperatures in the north and warm temperatures in the south, gradually reduce from south to north. The plains regions are warm, and the plateau regions are cold; the eastern average isotherms are approximately parallel to the weft; and the latitude factors are significant. In the western region, the average isotherm is approximately parallel to the contour line and is significantly affected by terrain factors. The lowest point of the average temperature is observed in the Qinghai-Tibet Plateau, whereas the highest point of the average temperature is observed in the South China Sea (Xisha). An ice-snow tourist destination must have both a cold climate and appropriate terrain. The temperature ranges from $-6{ }^{\circ} \mathrm{C}$ to $-15{ }^{\circ} \mathrm{C}$, as travelers can enjoy the fun of skiing, but also withstand the cold in this temperature range. If the temperature is too low and the snow is too hard, it will not be conducive to experiencing ice and snow tourism projects of the grade required for sports. As shown in Figure 2a, in regions with annual winter temperatures between $-30^{\circ} \mathrm{C}$ and $-18^{\circ} \mathrm{C}$, it is easy to maintain a landscape that includes snow and ice features, which is conducive to the development of indoor and outdoor ice-snow tourism products. The regions in China that are well suited for ice-snow tourism based on the winter temperature index are predominantly concentrated in the areas of Heilongjiang, Jilin, Inner Mongolia, Xinjiang, Tibet, Qinghai, and Ningxia, with the key cold-temperature cities being Harbin $\left(-7^{\circ} \mathrm{C}\right)$, Changchun $\left(-24^{\circ} \mathrm{C}\right)$, Yinchuan $\left(-18^{\circ} \mathrm{C}\right)$, and Hohhot $\left(-19^{\circ} \mathrm{C}\right)$. The cities that are relatively unsuitable are the coastal cities in Southeast China, such as Sanya, Guangzhou, and Fuzhou. 


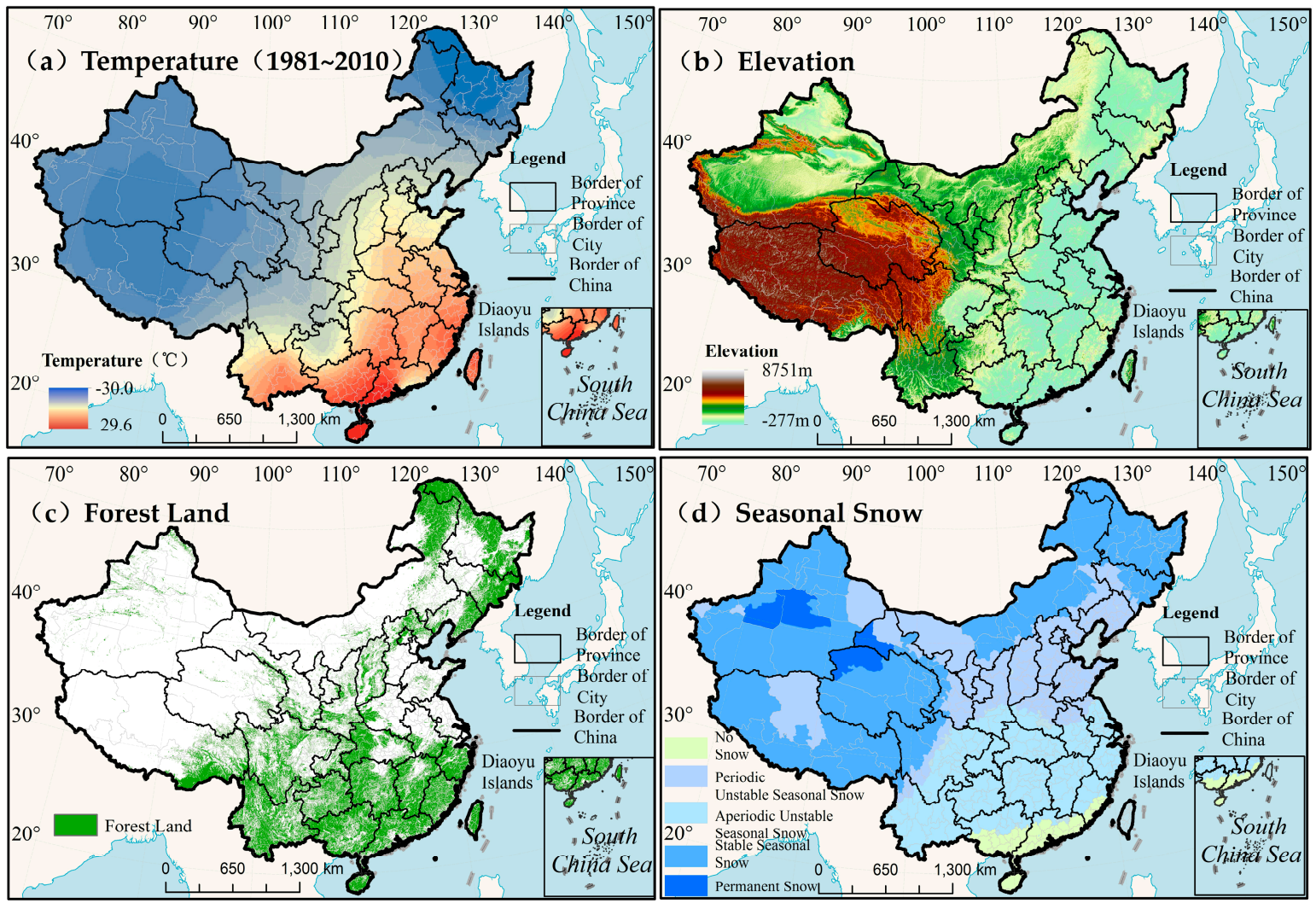

Figure 2. Resource and environment indicators of ice-snow tourist destinations.

China's overall terrain is high in the West and low in the East, showing a downward gradient, and this topography determines the flow direction of most rivers in China from west to east. As a result of the distribution of the ladder-like features, which causes a humid ocean air flow in the east, a gradual decline in westward precipitation is observed. The precipitation distribution causes differences in the water resources distribution. As shown in Figure 2b, the snow line in China tends to be low in the northeast and high in the southwest. The border areas in the western part of China are surrounded by snow-covered mountains. In more northern regions, the snow line is lower, and western regions are more arid and have a higher snow line. The northwestern area of Tibet has the highest elevation and the highest snow line in China. To develop appropriate tourism products, ice-snow tourism typically requires that the total hill and mountain area in the tourism region be greater than the plains area and the elevation be below $4500 \mathrm{~m}$. Regions in China that are well suited for ice-snow tourism, based on the elevation of the snow line, are in the northeastern and northwestern parts of the country. In particular, the elevation of the snow line is relatively high in arid regions, such as Tibet, which is not suitable for most tourists, and the difficulties and cost of development in that region are relatively high. However, the region can be developed as a special ice-snow tourism product.

Due to historical and natural geographical conditions, the distribution of forest resources in China is uneven. The northeast, southwest, and southeastern provinces have a greater number of forest resources. Differences in North China, the Central Plains and the northwest provinces are observed in the forest resources distribution [24]. As shown in Figure 2c, the spatial distribution of forests in China demonstrates that the southeastern and northeastern areas are significantly more forested than the northwestern plateau. The pattern of forest coverage in China has intertwined latitudinal, longitudinal and vertical zonal distributions. The regions that are well suited for ice-snow tourism based on forest coverage are in the southeast and northeast, where the landscape consists primarily of low and moderate hills, the annual rainfall is high, and the forest coverage is dense; these areas 
include Daxinganling, Xiaoxing'anling, and the Changbai Mountains. The region that is relatively unsuitable is the inland area in Northwest China, which has the least amount of forest coverage.

According to the length of snow duration, the season is divided into permanent snow and winter season snow. Seasonal snow is divided into stable snow (more than two months) and unstable snow (less than two months). As shown in Figure 2d, permanent snow is sporadically distributed in alpine glaciers in the western mountains. The stable snow area is primarily north of Tianshan in Xinjiang, in Daxinganling in Northeast China, north of Xiaoxing'anling, east of the Changbai Mountains, and in the Tanggula and Bayanula Mountains in the Tibetan Plateau. Some areas in Southwest China, such as some of the plateaus or mountains in the northern part of Yunnan Province, have unique "spring snow" landscapes that exhibit vertical ecological landscapes characteristic of snowy regions, including glaciers, alpine areas, meadows, snow-covered mountains, and water. This type of area is well suited for ice-snow tourism based on the snow distribution index. The unsuitable snow lines are predominantly distributed north of $24^{\circ} \mathrm{N}$ latitude and the Nanling Mountains. Areas without snow include Fujian, Guangdong, Guangxi, the southern part of Yunnan Province (District), and Hainan Province. These areas are relatively unsuitable for ice-snow tourism.

\subsection{Development Status Index}

As shown in Figure 3a, among the 32 provinces, autonomous regions and municipalities in China, the regions in which the density of coastal scenic areas is greater than the number of inland scenic areas are Jiangsu Province, Zhejiang Province, Henan Province, and Guangdong Province; tourism is highly developed in these areas [25]. In particular, the 5A-level scenic areas for ice-snow tourism and the resources that influence ice-snow tourism are distributed in Heihe City, Harbin City, Mudanjiang City, and Mohe County in Heilongjiang Province, Changchun City and Jilin City in Jilin Province, Lijiang City in Yunnan Province, Altay County in the Xinjiang Autonomous Region, and Hulun Buir in Inner Mongolia. Those cities listed in Table 3 that have both high revenues from tourism and high rankings on the tourism reception scale include Harbin, Changchun, Hohhot, Urumqi, and Lhasa. Summarizing the information above reveals that Northeast China has formed an entirely integrated industry circle for ice-snow tourism and the region is the national leader in the development of multiple scenic areas involving ice and snow; its ice-snow tourism industry has a broad scope and significant influence, and its suitability according to the development status index for ice-snow tourism is the highest. The Beijing-Tianjin-Hebei, Inner Mongolia, Gansu, Ningxia, and Qinghai regions are comparatively unsuitable due to the lack of core scenic areas featuring snow and ice [26-28].

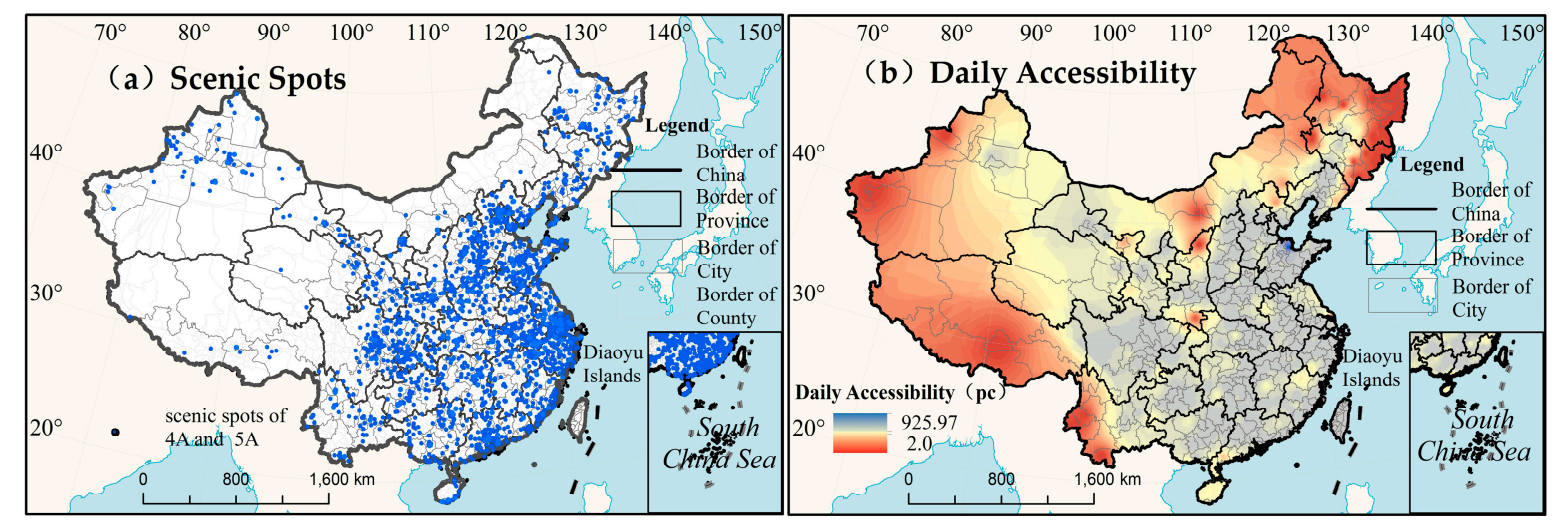

Figure 3. Indicators of current Chinese ice-snow tourism development. 
Table 3. Statistical data on the development of tourism in China in 2016.

\begin{tabular}{|c|c|c|c|c|c|c|c|}
\hline Ranking & $\begin{array}{c}\text { Province } \\
\text { (Municipalities } \backslash \\
\text { Autonomous } \\
\text { Region) }\end{array}$ & $\begin{array}{l}\text { Total } \\
\text { Tourism } \\
\text { Revenue } \\
\text { (Billion) }\end{array}$ & $\begin{array}{l}\text { Year-on- } \\
\text { Year } \\
\text { Growth } \\
(\%)\end{array}$ & Ranking & $\begin{array}{c}\text { Province } \\
\text { (Municipalities } \backslash \\
\text { Autonomous } \\
\text { Region) }\end{array}$ & $\begin{array}{l}\text { Total } \\
\text { Tourism } \\
\text { Revenue } \\
\text { (Billion) }\end{array}$ & $\begin{array}{l}\text { Year-on- } \\
\text { Year } \\
\text { Growth } \\
(\%)\end{array}$ \\
\hline 1 & Guangdong & 11560 & 11.50 & 16 & Liaoning & 4225 & 12.50 \\
\hline 2 & Jiangsu & 10263 & 13.40 & 17 & Guangxi & 4191 & 28.80 \\
\hline 3 & Zhejiang & 8093 & 13.40 & 18 & Fujian & 3935 & 25.30 \\
\hline 4 & Shandong & 8031 & 13.70 & 19 & Shanghai & 3820 & 9.00 \\
\hline 5 & Sichuan & 7706 & 24.10 & 20 & Shaanxi & 3813 & 26.78 \\
\hline 6 & Henan & 5764 & 14.47 & 21 & Tianjin & 3100 & 10.90 \\
\hline 7 & Guizhou & 5027 & 43.00 & 22 & Jilin & 2897 & 25.15 \\
\hline 8 & Beijing & 5021 & 9.00 & 23 & Inner Mongolia & 2715 & 20.28 \\
\hline 9 & Jiangxi & 4993 & 37.27 & 24 & Chongqing & 2645 & 17.50 \\
\hline 10 & Anhui & 4932 & 20.00 & 25 & Heilongjiang & 1603 & 17.76 \\
\hline 11 & Hubei & 4870 & 13.00 & 26 & Xinjiang & 1401 & 37.00 \\
\hline 12 & Yunnan & 4726 & 44.10 & 27 & Gansu & 1220 & 25.00 \\
\hline 13 & Hunan & 4707 & 26.79 & 28 & Hainan & 670 & 16.97 \\
\hline 14 & Hebei & 4655 & 35.60 & 29 & Tibet & 331 & 17.30 \\
\hline 15 & Shanxi & 4247 & 23.19 & 30 & Qinghai & 310 & 25.10 \\
\hline
\end{tabular}

As shown in Figure 3b, traffic accessibility has significant influence on the selection of ice-snow tourism destinations [29]. The amount of time spent on the road traveling determines the overall convenience of a tourist destination. The accessibility discussed in this paper includes traditional railroads, high-speed railroads, airports, highways, and ports, and the daily accessibility is used as an index in the analysis. Since four hours is generally considered to be a comfortable length of time to travel by these transportation methods, four hours is used as the range in the calculations. Northwest China and some areas of Northeast China are considered to be poorly accessible, but the coastal areas and North China are otherwise considered to be accessible. Representative regions that are easily accessible and considered suitable are Beijing, Tianjin, Harbin, Changchun, Shenyang, Changsha, Shanghai, Wuhan, Urumqi, and Hohhot. Representative regions that are difficult to access and considered unsuitable are Kashgar, Lhasa, Qiqihar, and Yichun [30].

\subsection{Industry Potential Index}

Population size and economic level are important indices for evaluating the potential for regional tourism industries. Statistics on the population and GDP from 2016 for each Chinese city with level $5 \mathrm{~A}$ ice-snow scenic areas are presented in Table 4. Based on Figure 4a,b, the economy is considered developed in the ten major urban agglomerations in China, where the population is dense, the per capita GDP is high, and the tourism industry has high potential. However, in addition to the ten major urban agglomerations, the central part of Hunan Province, centered at Changsha-Zhuzhou-Xiangtan, the central part of Jilin Province, centered at Changchun and Jilin City, the central and northern parts of Heilongjiang Province, centered at Harbin, the Beibu Bay urban agglomeration centered at Nanning and the northern slopes of the Tianshan Mountains, centered at Urumqi, all have the potential to develop new, relatively large-scale urban agglomerations. The population scale and per capita disposable income are relatively high in these areas, which can help in the development of ice-snow tourism. In particular, central Jilin, the northern part of Heilongjiang and the Tianshan Mountains in Urumqi, which are regions with abundant resources for ice-snow tourism, are considered suitable for industry development. Economic development in these regions is stable, which is in compliance with the national development strategy, and the ice-snow tourism industry has a high potential for development [31,32]. 


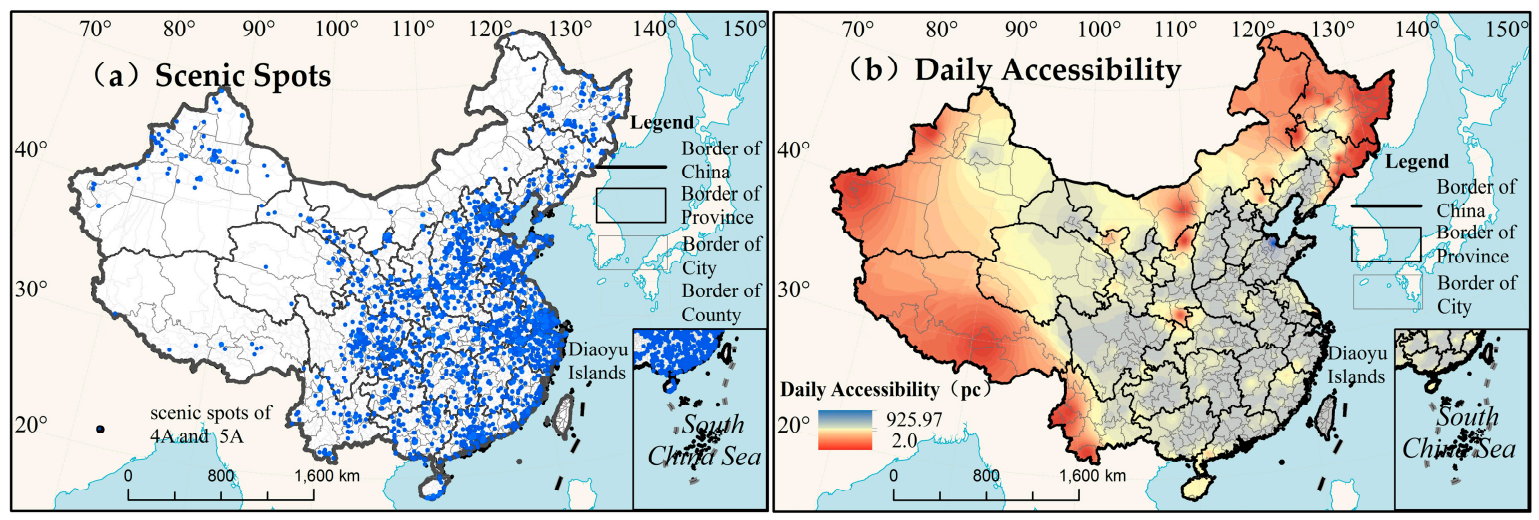

Figure 4. The ice-snow tourism potential index for China.

Table 4. Statistical data on the population and economies of major ice-snow tourism provinces (autonomous regions) and cities (autonomous prefectures).

\begin{tabular}{|c|c|c|c|c|}
\hline $\begin{array}{c}\text { Coastal Province } \\
\text { (Direct-Controlled Municipality, } \\
\text { Autonomous Region) }\end{array}$ & $\begin{array}{l}\text { Major Ice-Snow } \\
\text { Tourism City }\end{array}$ & $\begin{array}{l}\text { Total Population } \\
\quad(\times 10,000)\end{array}$ & $\begin{array}{l}\text { Population of Urban } \\
\text { Area }(\times 10,000)\end{array}$ & $\begin{array}{c}\text { Per Capita GDP } \\
\text { (RMB Yuan) }\end{array}$ \\
\hline \multirow{4}{*}{ Heilongiiang Province } & / & 3833 & 3155.4 & 42,928 \\
\hline & Harbin & 944.4 & 427.5 & 50,423 \\
\hline & Heihe & 171.5 & 21.0 & 22,654 \\
\hline & Mudanjiang & 259.8 & 89.0 & 46,953 \\
\hline \multirow{3}{*}{ Jilin Province } & / & 2475.9 & 863.3 & 54,997 \\
\hline & Changchun & 754.8 & 363.4 & 66,443 \\
\hline & $\begin{array}{l}\text { Yanbian Chao } \\
\text { Autonomous Prefecture }\end{array}$ & 218.6 & 139.1 & 24,900 \\
\hline \multirow{2}{*}{ Xinjiang } & / & 298.1 & 292.0 & 40,569 \\
\hline & $\begin{array}{c}\text { Changji Hui } \\
\text { Autonomous Prefecture }\end{array}$ & 169.4 & / & 72,261 \\
\hline \multirow{2}{*}{ Yunnan Province } & / & 2864.0 & 639.8 & 28,918 \\
\hline & $\begin{array}{c}\text { Lijiang Naxi } \\
\text { Autonomous Prefecture }\end{array}$ & 119.5 & 15.1 & 21,908 \\
\hline
\end{tabular}

\section{Results and Discussion}

\subsection{Results}

Since ice-snow tourism is an environment-oriented tourism product, its seasonality is strongly correlated to latitude; therefore, as shown in Figure 5 and Table 5,we identify those regions of China that are well suited to ice-snow tourism to be predominantly concentrated at latitudes between $35^{\circ} \mathrm{N}$ and $53^{\circ} \mathrm{N}$. Due to terrain, some of the regions considered suitable are located at latitudes between $41^{\circ} \mathrm{N}$ and $45^{\circ} \mathrm{N}$ and longitudes between $82^{\circ} \mathrm{E}$ and $90^{\circ} \mathrm{E}$. Due to the low latitude and the influence of the Kuroshio Current (a warm ocean current), regions at a latitude of $20^{\circ} \mathrm{N}-35^{\circ} \mathrm{N}$ and longitude of $100^{\circ} \mathrm{E}-122^{\circ} \mathrm{E}$ are considered unsuitable; such representative regions include the Yangtze River Delta, the Pearl River Delta, the Shandong Peninsula urban agglomeration, the mid-Southern Liaoning urban agglomeration, the Central Plains urban agglomeration, the urban agglomeration in the middle reaches of the Yangtze River, the urban agglomeration on the west side of the Taiwan Strait, the Sichuan-Chongqing urban agglomeration, and the Guanzhong urban agglomeration.

In Xinjiang and Tibet, snow and ice are abundant and lasting. However, the regional population density is small, and the tourism industry is underdeveloped. Moreover, snow and ice are largely distributed along the plateau and in the mountains, where traffic accessibility is relatively poor. The challenges facing ice-snow tourism industry exploration and development are great, although there is ample opportunity to provide unique ice-snow tourism that is stimulating and challenging. In regions with positive development trends in the tourism industry that are otherwise unsuited to 
ice-snow tourism, only large cities, such as Shanghai and Shenzhen, can provide indoor ice-snow tourism using technological innovation.

In Inner Mongolia, which is a suitable ice-snow tourism destination, especially in the eastern area, the area available to visitors is vast, and the snow and ice resources are richly endowed by nature. This region also has a landscape that includes mountains and forests and is easily accessible to traffic, which makes it very easy to provide a package of ice-snow tourism opportunities. It is appropriate to creatively develop ice-snow tourism, improve the quality of service provided, and construct ski venues and sightseeing areas for ice-snow tourists. In the Beijing-Tianjin-Hebei area, the economy is developed and population density is high. Therefore, the potential for developing an ice-snow tourism industry is high, given the market demand, advantageous location with respect to traffic, and the availability of artificial resource development techniques. By adopting a method that combines natural ice-snow tourism with artificial ice-snow tourism products, profits can be increased in the ice-snow tourism industry.

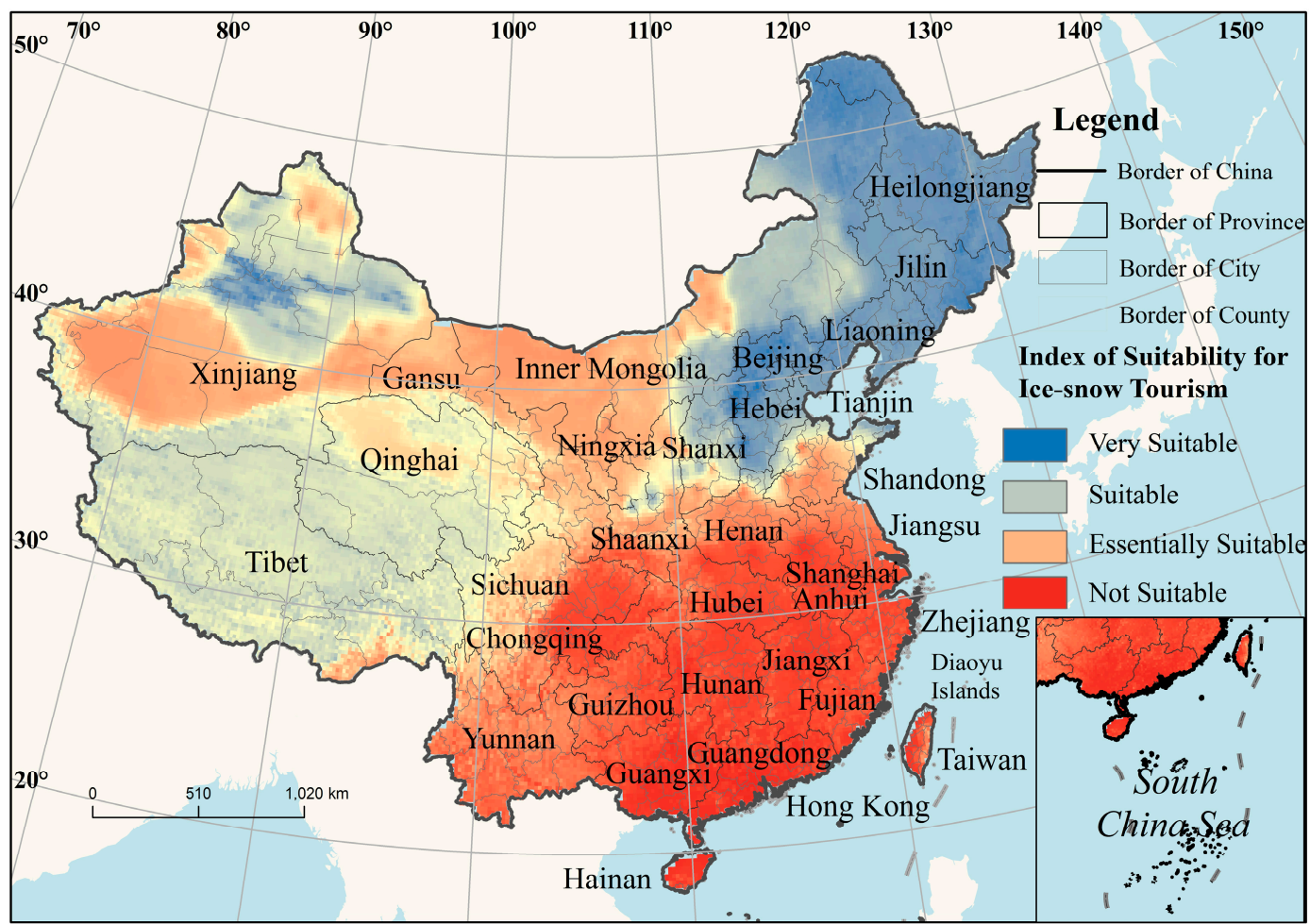

Figure 5. Suitability grades for ice-snow tourist destinations in China.

Table 5. Rating assessment based on the suitability index for ice-snow tourism in China.

\begin{tabular}{ll}
\hline Suitability Grade for Ice-Snow Tourism & Spatial Distribution \\
\hline Very suitable for ice-snow tourism & $\begin{array}{l}\text { Central area of Heilongiiang Province, central and eastern areas of Jilin } \\
\text { Province, western and northern areas of Liaoning Province, Beijing, } \\
\text { Tianjin, Hebei Province, region near the Tianshan Mountains in Xinjiang }\end{array}$ \\
\hline Suitable for ice-snow tourism & $\begin{array}{l}\text { Tibet, most of Qinghai, central and northern areas of Xinjiang, eastern } \\
\text { area of Inner Mongolia }\end{array}$ \\
\hline Moderately suitable for ice-snow tourism & $\begin{array}{l}\text { Gansu, Ningxia, western and southern areas of Xinjiang, western area of } \\
\text { Inner Mongolia and northern area of Sichuan }\end{array}$ \\
\hline Not suitable for ice-snow tourism & Southeastern area of China and areas without periodic, stable snowfall \\
\hline
\end{tabular}




\subsection{Conclusions}

This study investigates the spatial difference of the suitability of snow and ice tourism destinations to facilitate tourism projects of all types of tourism in China, according to the inherent resources. The development of appropriate tourism projects aims to improve the competitiveness of tourism and extend the life cycle of a scenic area. The tourism market is multi-level, exhibits a diversified development trend, and includes static and dynamic tourism participatory tourism changes, and ice and snow eco-tourism. According to the resources and development status and the potential to analyze appropriate development methods, the research is based on the comprehensive analysis of the ice and snow tourism industry foundation, the development state and the development potential, to determine the spatial difference of the suitability of China's ice and snow tourism destination. Conclusions of the research are as follows:

(1) Taking into account the three factors, which are dependent on the city + tourist area development model, which considers the difference between the dependence on ice and snow resources and the status of urban development considerations, China's ice and snow tourism destination is better suited to the Heilongjiang region in Jilin central city, Xinjiang and some cities in Hebei Province; Harbin (longitude $125^{\circ} 42^{\prime}-130^{\circ} 10^{\prime}$, latitude $44^{\circ} 04^{\prime}-46^{\circ} 40^{\prime}$ ), Changchun (longitude $124^{\circ} 18^{\prime}-127^{\circ} 02^{\prime}$, latitude $43^{\circ} 05^{\prime}-45^{\circ} 15^{\prime}$ ), Changji Hui Autonomous Prefecture (east longitude $86^{\circ} 24^{\prime}-87^{\circ} 37^{\prime}$, latitude $43^{\circ} 06^{\prime}-45^{\circ} 20^{\prime}$ ) and Zhangjiakou (longitude $113^{\circ} 50^{\prime}-116^{\circ} 30^{\prime}$, latitude $\left.39^{\circ} 30^{\prime}-42^{\circ} 10^{\prime}\right)$. China's ice and snow resources are limited to the northeastern region of ice and snow tourism development in the scale and impact of a leading position. The resources and environmental advantages of an outstanding ice and snow tourism industry development is substantial.

(2) The snow and ice resources and the development of an urban development status has improved with the potential for the development of cities in the western region of China. Tibet (longitude $78^{\circ} 25^{\prime}-99^{\circ} 06^{\prime}$, latitude $26^{\circ} 44^{\prime}-36^{\circ} 32^{\prime}$ ), Qinghai (east longitude $89^{\circ} 41^{\prime}-103^{\circ} 07^{\prime}$, latitude $31^{\circ} 41^{\prime}-39^{\circ} 07^{\prime}$ ) and other places have stable ice and snow resources but a small scale and underdeveloped economy. The Inner Mongolia $97^{\circ} 21^{\prime}-126^{\circ} 07^{\prime}$, latitude $37^{\circ} 41^{\prime}-53^{\circ} 38^{\prime}$ ) area's mountains and rivers are rich in forest resources, have unique winter snow and ice resources, and have a long period of snowfall; this city can easily implement ice and snow tourism projects.

(3) Northern China does not have sufficient snow and ice resources. As the center of the social and economic advantages of its ice and snow tourism industry, the city of Beijing has to rely on market demand, traffic location advantages and artificial development technology, which occupy a relatively small part of the snow and ice market share. Tourism development and the potential of the large southeast and coastal cities, which do not have snow and ice tourism resources and are not suitable for outdoor snow and ice tourism projects, are lacking. Individual large cities have to consider the cost and effectiveness of the construction of urban artificial ice and snow and snow and ice leisure travel.

\subsection{Discussion}

Ice-snow tourism in China can be developed by depending on the distribution of snow and ice in the northern area of China and the plateau area [33]. Due to differences in natural resource availability and cities with snow and ice resources, the potential for the development of ice-snow tourism in different parts of China is variable. Northeast China possesses many ice-snow tourism resources, including lake water, mountains, and an ice and snow art museum. The ice-snow tourism industry in Northwest and Southwest China is primarily dependent on its snow-capped mountains and ecological experience opportunities. In the regions that are most suitable for the development of ice-snow tourism in China [34], Northeast China is the core region for ice-snow tourism. The ice-snow tourism area of Harbin is concentrated on the Sun Island Scenic Area, which connects the two-way Wudalianchi Scenic Area in Heihe and the Jingpo Lake Scenic Area in Mudanjiang, where the development 
of comprehensive ice-snow tourism with major ice and snow festivals and minor geological and lake tours occur. The Changchun-Yanji ice-snow tourism area has developed ice-snow tourism by integrating it with sightseeing, entertainment, and sport. The Tianshan Tianchi Scenic Area in the Changji Hui Autonomous Prefecture in Xinjiang is the center of ice-snow tourism in Northwest China; there, one ice-snow tourism product is slowly being developed. A rather unique ice-snow tourism destination in China is the Yulong Snow Mountain Scenic Area in Naxi Autonomous County in Lijiang, where ice-snow tourism has been developed based on the area's snow and ice resources and vertical ecology; it is part of a tourism circle that contains many cultural and natural scenic locations in the surrounding area.

However, for the present study, because of the data collection process, the selection of an evaluation index and relevant statistics are subject to the issues of comparability, and the objectivity and accuracy of the quantitative analysis results are subject to certain constraints. For example, some data, such as temperature distribution, are obtained using spatial interpolation, and there are some deviations from the actual data. Therefore, quantitative studies of the spatial heterogeneity of the suitability of ice-snow tourism destinations require further scientific improvement.

Acknowledgments: This research study was supported by the National Natural Science Foundation of China (grant no. 41471140) and the Liaoning Province Outstanding Youth Program (grant no. LJQ2015058). The authors would like to acknowledge all experts' contributions in the building of the model and the formulation of the strategies in this study.

Author Contributions: Jun Yang contributed to all aspects of this work; Ruimeng Yang wrote the main manuscript text and conducted the experiment; Tai Huang and Jing Sun analyzed the data; and Quansheng Ge and Tai Huang revised the paper. All authors reviewed the manuscript.

Conflicts of Interest: The authors declare no competing financial interests.

\section{References}

1. Fischer, A.; Olefs, M.; Abermann, J. Glaciers, snow and ski tourism in Austria's changing climate. Ann. Glaciol. 2011, 52, 89-96. [CrossRef]

2. May, V. Environmental implications of the 1992 Winter Olympic Games. Tour. Manag. 1995, 16, 269-275. [CrossRef]

3. Sharpley, R. Snow Business: A Study of the International Ski Industry. Tour. Manag. 2002, 23, 419-425. [CrossRef]

4. Dewar, K.; Meyer, D.; Wen, M.L. Harbin, lanterns of ice, sculptures of snow. Tour. Manag. 2001, 22, 523-532. [CrossRef]

5. Scott, D.; McBoyle, G.; Minogue, A.; Mills, B. Climate Change and the Sustainability of Ski-based Tourism in Eastern North America: A Reassessment. J. Sustain. Tour. 2006, 14, 376-398. [CrossRef]

6. Burakowski, E.; Magnusson, M. Climate Impacts on the Winter Tourism Economy in the United States; The Natural Resources Defense Council: New York, NY, USA, 2012.

7. DemiRoglu, O.C.; Turp, M.T.; Ozturk, T.; Kurnaz, M.L. Impact of climate change on natural snow reliability, snowmaking capacities, and wind conditions of ski resorts in Northeast Turkey: A dynamical downscaling approach. Atmosphere 2016, 7, 52. [CrossRef]

8. Scott, D.; Dawson, J.; Jones, B. Climate change vulnerability of the US Northeast winter recreation-Tourism sector. Mitig. Adapt. Strateg. Glob. Chang. 2008, 13, 577-596. [CrossRef]

9. Chen, Z.W.; Zhang, Q. The Orientation and Developing Proposition of Ice Tourism in Jilin Province. J. Jilin Norm. Univ. 2005, 26, 32-33. (In Chinese)

10. Huang, C. Harbin construction and the world of ice and snow tourist city of strategic thinking. Heilongjiang Local Chron. 2004, 5, 31-33. (In Chinese)

11. Yu, T.F.; Gu, C.L.; Wang, H.; Duan, X.J.; Yi, X.F. The evaluation and analysis of the tourism resources in Jilin Province. Chin. Geogr. Sci. 2002, 12, 186-192. [CrossRef]

12. Spina, L.D.; Ventura, C.; Viglianisi, A. Enhancement and Governance of the Local Tourist Destinations in Integrated Perspective. Procedia Soc. Behav. Sci. 2016, 223, 327-334. [CrossRef] 
13. Freitas, C.R.D. Tourism climatology: Evaluating environmental information for decision making and business planning in the recreation and tourism sector. Int. J. Biometeorol. 2003, 48, 45-54. [CrossRef] [PubMed]

14. Claveria, O.; Poluzzi, A. Positioning and clustering of the world's top tourist destinations by means of dimensionality reduction techniques for categorical data. J. Destin. Market. Manag. 2016, 1, 1-11. [CrossRef]

15. Tang, Q.; Li, Y.; Xu, Y. Land suitability assessment for post-earthquake reconstruction: A case study of Lushan in Sichuan, China. J. Geogr. Sci. 2010, 65, 164-176. [CrossRef]

16. Cui, L.; Wu, K.; Tseng, M. Exploring a Novel Agricultural Subsidy Model with Sustainable Development: A Chinese Agribusiness in Liaoning Province. Sustainability 2017, 9, 19. [CrossRef]

17. Mérida, A.L.; Carmona, M.; Congregado, E.; Golpe, A.A. Exploring the regional distribution of tourism and the extent to which there is convergence. Tour. Manag. 2016, 57, 225-233. [CrossRef]

18. Song, H.; Li, G. Tourism demand modelling and forecasting-A review of recent research. Tour. Manag. 2008, 29, 203-220. [CrossRef]

19. Hong, Z.; Guo, Y. A study on the spatial flow intensity of overseas travelers in tourist hotspots of China_taking Beijing as an example. J. Chin. Geogr. 2000, 1, 79-83.

20. Mutinda, R.; Mayaka, M. Application of destination choice model: Factors influencing domestic tourists destination choice among residents of Nairobi, Kenya. Tour. Manag. 2012, 33, 1593-1597. [CrossRef]

21. Dietz, A.J.; Kuenzer, C.; Dech, S. Analysis of Snow Cover Time Series-Opportunities and Techniques. In Remote Sensing Time Series; Springer: Cham, Switzerland, 2015; pp. 75-98.

22. Li, Y.; Zhao, M.Y.; Guo, P.; Zheng, J.; Li, Z.H.; Li, F.J.; Shi, Y.Y.; Dong, S.C. Comprehensive evaluation of ski resort development conditions in northern China. Chin. Geogra. Sci. 2016, 26, 401-409.

23. Tervo, K. The operational and regional vulnerability of winter tourism to climate variability and change: The case of the Finnish nature-based tourism entrepreneurs. Scand. J. Hosp. Tour. 2008, 8, 317-332. [CrossRef]

24. Xie, G.D.; Li, W.H.; Xiao, Y.; Zhang, B.; Lu, C.X.; An, K.; Wang, J.X.; Xu, K.; Wang, J.Z. Forest ecosystem services and their values in Beijing. Chin. Geogra. Sci. 2010, 20, 51-58.

25. Li, R.; Guo, Q.; Wu, D.T.; Zhu, T.X. Spatial characteristics of development efficiency for urban tourism in eastern China: A case study of six coastal urban agglomerations. J. Geogr. Sci. 2014, 24, 1175-1197. [CrossRef]

26. Zhang, L.; Zhang, X.M. Heilongjiang Ice-Snow Tourism Industry Competitiveness Evaluation Index System Design; Springer: Berlin/Heidelberg, Germany, 2011; pp. 605-610.

27. Zhang, Y. Analysis and Prediction of the Total Number of Harbin Ice-Snow Tourism Based on Times Series; Springer: Berlin/Heidelberg, Germany, 2012; pp. 495-501.

28. Pan, J.H.; Cong, Y.B. Spatial Accessibility of Scenic Spot at 4 A Level and Above in China. Sci. Geogr. Sin. 2012, 32, 1321-1327.

29. Jin, Q.; Hu, H.; Philip, K. Factors Influencing Perceived Crowding of Tourists and Sustainable Tourism Destination Management. Sustainability 2016, 8, 976. [CrossRef]

30. Pan, J.H.; Cong, Y.B. Tourism Regionalization in China Based on Spatial Accessibility of A-grade Scenic Spots. Sci. Geogr. Sin. 2014, 34, 1161-1168.

31. Karl, M. Risk and Uncertainty in Travel Decision-Making: Tourist and Destination Perspective. J. Travel Res. 2016, 1-18. [CrossRef]

32. Zheng, Q.; Kuang, Y.; Huang, N. Coordinated Development between Urban Tourism Economy and Transport in the Pearl River Delta, China. Sustainability 2016, 8, 1338. [CrossRef]

33. Zhu, H.; Liu, J.M.; Chen, C.; Lin, J.; Tao, H. A spatial-temporal analysis of urban recreational business districts: A case study in Beijing, China. J. Geogr. Sci. 2015, 25, 1521-1536. [CrossRef]

34. Zhou, X.; Chen, X.H.; Zhang, T.R. Impact of Megacity Jobs-Housing Spatial Mismatch on Commuting Behaviors: A Case Study on Central Districts of Shanghai, China. Sustainability 2016, 8, 122. [CrossRef]

(C) 2017 by the authors. Licensee MDPI, Basel, Switzerland. This article is an open access article distributed under the terms and conditions of the Creative Commons Attribution (CC BY) license (http:/ / creativecommons.org/licenses/by/4.0/). 